Rethinking Britain and the European Union: politicians, the media and public opinion reconsidered

Paul Copeland

School of Politics and International Relations

Queen Mary University of London

Mile End Road

London

E1 4NS

And

Nathaniel Copsey

Politics and International Relations

Aston University

B4 7ET 


\section{Rethinking Britain and the European Union: politicians, the media and public opinion reconsidered ${ }^{1}$}

\section{Introduction}

For more than 40 years since the British accession to the then Common Market in 1973, the UK's relationship with the European project could be characterised as fragile and sceptical. Following Wilson's brief renegotiation in 1974, the UK’s 1975 referendum produced a majority in favour of continued membership (67 per cent with a turnout of 65 per cent). Whilst the membership question was never fully dropped, a cross-party consensus existed, although both the Labour and Conservative parties contained Eurosceptic factions. The enduring fragile consensus was based on a form of economic integration that incurred neither large budgetary cost, nor led to an erosion of Britain's sovereignty. This grudging cross-party consensus changed in January 2013. That month, Prime Minister David Cameron announced that if the Conservative party were to form the government after the 2015 general election, it would hold an 'in-or-out' referendum on the renegotiated terms of Britain's membership before the end of 2017. It is worth briefly exploring the recent historical background to this change.

From the early 1990s to the mid-2010s, EU-wide and UK-specific pressures to hold a referendum steadily increased. Cameron's EU referendum promise can be seen as one instance of several EU-wide political trends that form part of a post-Maastricht shift across the EU from 'permissive consensus to constraining dissensus' (Hooghe and Marks 2009). Within the Member States decisions can no longer be legitimised by executives and legislatures alone. On EU matters the public demands a say through referendums (although the call for a UK referendum has as much to do with infighting within the Conservative Party). Mair (2007) argued that the depoliticisation of EU politics drove this dynamic. Where there is consensus between mainstream political parties on EU policies, opposition to the EU shifts towards questioning the fundamental principles of integration. The argument can be taken further: Kriesi et al.

\footnotetext{
${ }^{1}$ The authors would like to acknowledge the invaluable research assistance of Dr Anne-Claire Marangoni and Sara Ewing, comments on earlier drafts by Tim Bale, Simon Bulmer, Tim Haughton and William Patteson, as well as the three anonymous reviewers of JCMS and the editors.
} 
argue that the shift in politics, parties and party systems across the EU is driven by structural competition between the winners and losers of globalisation (Kriesi et al. 2006, p. 921), of which the EU is a regional variant (Schmidt, 2003).

Growing pressure to hold a referendum in the UK has been linked to the growth of Euroscepticism as a political phenomenon. The rapid growth of British Euroscepticism is best evidenced by the United Kingdom Independence Party's (UKIP) topping the polls in the 2014 European Parliamentary Elections with more than 27 per cent of the popular vote. For Fontana and Parsons (2015) pressure for a referendum had been building in the Conservative Party since the early 1990s, as Euroscepticism became the default position for those who saw themselves as Thatcher's heirs after her fall from power in 1990. The 'mechanisms pointing to a “Brexit” referendum were largely in place’ by 2005 (Fontana and Parsons, 2015, p. 102) because the Conservative party by then had a clear majority of Eurosceptics, often with deep connections to the constituency level. This shift in British politics extended beyond the Conservative party. Labour Prime Minister Tony Blair promised referendums on both Euro membership (which was never needed because the 'five economic tests' were not met) and the Constitutional treaty (which was negated by the French and Dutch rejection of it in 2005) (Oppermann, 2008). To prevent a reoccurrence, in 2011, the Conservative-Liberal Democrat Coalition Government passed a European Union Act that committed the UK to holding national referendums before consent could be given to any deeper European integration. In 2012, the same Coalition Government commissioned a 'Balance of Competences Review' to evaluate what the EU does and how it affects the UK. By the 2010 General Election, even the pro-European Liberal Democrats began to support the idea of an 'in or out' referendum on EU membership to coincide with the next major revision of the treaties (Glencross, 2015).

Other scholars have pointed to the role of the UK media as key to understanding the rise of Euroscepticism. For Daddow (2012), increased Euroscepticism can be traced to Rupert Murdoch and News UK, while for Young (1999) and Forster (2002) the issue has its origins in the reporting of the right-wing press, which includes the publications of News UK. For Hawkins (2012: 562) the negative reporting of the EU in the UK is more problematic than in other EU Member States since the public is the 
least well informed about EU developments. The existing literature suggests that newspapers and the voters who read them are divided between an indifferent costbenefit motivated majority for whom the European Union is a matter of rational choice on the one hand; and, a vocal minority element within society for whom almost anything to do with the European Union must be exclusively negative, on the other.

This brief tour of the literature has set out some of the underlying driving forces that led to the 2016 UK referendum on EU membership. But as Prosser (2016, p. 197) argues 'further empirical investigation into the domestic political structures that drive the domestic politics of European integration is needed'. We take up this mantle with regard to just one factor: the role of the media as a vital intermediary between politicians and the public. In any national debate about membership of the EU, the media has a significant part to play in informing the public, as well as politicians and policy-makers, about the reasoned choices that need to be made and their consequences. And as Gavin (2000) points out, the media is where the public gets its information on EU affairs. In this article we describe and analyse how the 'European issue' has been reported in the British print media over the 40 years from the mid1970s to the mid-2010s. In doing so we provide a longitudinal empirical study that moves beyond the focus on Rupert Murdoch, the Eurosceptic press, and the political events of the early 1990s as being the determining factor in the EU debate within the UK. While each of these are necessary to understand the UK/EU debate, in isolation of each other they are insufficient and their individual significance could be overstated. For example, the UK press is an important component of the UK debate on the EU; but it is not the only determinant - public opinion and national politics are equally significant. We argue that the relationship between the media, national politics and public opinion is symbiotic and mutually dependent. We therefore begin our analysis of the 'European issue' in the UK from this assumption, rather than the supposition that one aspect of the relationship is the determinant of the other two.

The paper investigates empirically whether the EU debate in the UK has succumbed to a structural bias in favour of Euroscepticism. In doing so, it provides empirical evidence that helps test the concept of 'issue capture' as a means of explaining the British debate on the EU that was put forward by Copsey and Haughton (2014). Issue- 
capture refers to the way in which a political issue of marginal interest to the mainstream can be captured and dominated by a minority group, with strongly held opinions, and for whom it has a particular salience (Copsey \& Haughton, 2014, p. 2014). The evidence gathered in our dataset explores this concept and supports the proposition that 'issue capture' has occurred. Central to the process is the absence of a pro-European faction within the British polity that is able to promote and defend the EU and to counter Eurosceptic rhetoric. We argue therefore that the growth of Euroscepticism in the UK is more likely to be the result of this general dynamic, rather than any single event or the agency of individuals, such as Margaret Thatcher or Rupert Murdoch.

We proceed as follows. Section I briefly overviews the existing literature on the question of Britain's media and the European issue. This exercise not only places our own work within the wider scholarly context, but it also allows us to explain how we arrived at our own research puzzle. Section II sets out the methodology with which a dataset of more than 16,400 press articles (1974-2013) covering the European issue was compiled. This allows us to explore how British press coverage of the European issue has varied over time. The relationship between UK attitudes and the EU is dynamic in that its evolution does not reflect an unchanging, fixed EU; rather it reflects a process of European integration that is in a state of flux. Our focus here is on the particular angle that the journalist took (positive, negative, factual or neutral) and the magnitude of that position in positive and negative reporting (low, medium and high). Section III presents the findings of the dataset, which illustrate the areas of continuity and change in British coverage of the European issue over the 40 years between the mid-1970s and mid-2010s. In section IV, we contextualise the findings with data on public opinion and developments within UK national politics. In the conclusion, we reflect on the significance of our findings for the politics of Britain and the European Union.

\section{The Media, Public Opinion and Political Agenda-Setting}

In any national debate about membership of the European Union, the media has a significant part to play in informing the public, as well as politicians and policymakers, about the reasoned choices that need to be made and their consequences. 
Over the 40 years since 1973, Daddow (2012) argues that UK media coverage on the EU moved from 'permissive consensus to destructive dissent'. Daddow makes a powerful case that the UK media is characterised by 'vigorously partisan hostility bordering on a nationalist and in some arenas xenophobic approach to coverage of European affairs' (2012, p. 1219).

The proximate cause of the decline in media neutrality for Daddow (2012) was identified in one person: the hugely successful media magnate Rupert Murdoch, proprietor of the Britain's best-selling tabloid newspaper The Sun, as well as the more highbrow Times and Sunday Times, to say nothing of Sky News, Fox News and his international holdings. Murdoch's personal instruction on editorial policy for coverage of the European issue is identified by Daddow (as well as Arsenault and Castells, 2008) as the direct source of negative coverage of European politics. Commercial gain, in other words, the bottom line of his News UK holding company, it is argued, forms the basis of Murdoch's fervent anti-Europeanism. Murdoch, it is reasoned, feared the possible effects of anti-monopoly European competition policy regulation on his companies' profitability. This prompted him to push for a strongly anti-European line in all his papers.

Young (1999) and Forster (2002) point to the broader impact of the right-wing newspapers, particularly The Daily Telegraph and The Times, which, in the early 1990s, began to align themselves with the Eurosceptic standpoint (with the latter owned by Murdoch since 1981). This coincided with a period of turbulence in both domestic politics and the UK-EU relationship. Not only did divisions over Europe within the Conservative Party contribute to the resignation of Margaret Thatcher, but the debate over the Maastricht Treaty caused serious long-term rifts within the Conservative party. At the same time as the Maastricht debate was taking placing in the UK and across Europe, Britain was also forced out of the Exchange Rate Mechanism in September 1992 (Geddes 2013), which in turn undermined both the Conservative party's reputation for economic competence for nearly 20 years and the wider perception that membership of the EU was good for the UK economy. All of this points to the early 1990s as being a period in which Euroscepticism emerged fully and began to dominate the political landscape. 
Hawkins' 2012 study looked at press coverage of the Constitutional and Lisbon treaties and identifies a eurosceptic discourse that predominates in the British media and 'dictates the terrain on which wider debates about the EU are conducted' (Hawkins, 2012, p. 561). This is of crucial importance since earlier research has shown that media framing of European integration correlated with both higher levels of support (positive framing) and greater levels of cynicism and opposition (De Vreese, 2007; Vliengenthardt et al., 2008). This is particularly important in a setting where the public know little about the EU. The British public is the least wellinformed about the workings of the EU of any Member State. It is amongst this least informed segment of the population where support for the EU falls the most when public discussion of European integration is pitched in terms of risk (De Vreese and Kandyla, 2009). Hawkins' identifies a British debate in which right wing press coverage of the EU reflects 'themes of separation and threat' (Hawkins, 2012, p. 573), where UK interests are 'excluded or marginalised' or 'undermined by EU integration'. Even in the left wing press, coverage is 'reactive to an agenda set by the Eurosceptic discourse’ (Hawkins, 2012, p. 573).

These different arguments regarding the role of the UK media each highlight a particular aspect of the British press to explain the uniqueness of Euroscepticism in the UK. While we do not seek to question the argument that the British press is Eurosceptic, or that the early 1990s were a key turning point for the UK-EU debate, we do question whether the rise of Euroscepticism can be traced to one event or one individual. We consider the relationship between the media, public opinion and agenda-setting in the UK to be more multi-dimensional than a simple linear causality. For example, although the Murdoch-owned News UK remains important, based on circulation figures for 2000-14, only one of the top five national newspapers (The Sun) is owned by News Corporation. The remainder (Daily Mail, Daily Mirror, Daily Telegraph, Express) are owned by a variety of publishers, all of which have their own political agendas. News UK is therefore an important player within the UK media, but to ascribe absolute political agency to it and its owner, is to draw a simplified connection between rising Euroscepticism and a single source. The logic of such an argument has striking similarities with the EU-UK debate itself: a foreigner (Rupert Murdoch is Australian and American) controlling a domestic political issue (the EUUK relationship) and imposing its will against which the UK is powerless to resist. If 
Murdoch's interests are commercial (which seems a reasonable supposition for a hugely successful businessman), then his prime motivation is selling newspapers or subscriptions to his television channels. The best means of doing so is to give the public the kinds of stories that they like. Although European politics has seldom been an issue in which the British public displayed a passionate interest (Copsey and Haughton, 2014), newspaper readers do have a deep attachment to a good story, the revelation of cover-ups, and for sensationalism in general. Whilst a not otherwise particularly interesting set of potential headlines about Europe ('new regulations for pleasure craft agreed' say) has been exchanged for sensationalism ('Brussels to ban square gin bottles'), this is a trend that is not exclusively linked to European affairs in UK Media ('Cancer chemicals are found in eggs', 'Does eating eggs make you generous?’ etc.).

News UK could, of course, exert its power as the 'pace-setter' of media reporting on the European issue, as well as numerous other topics. The logic here is that the taking of a position on the EU by the UK's largest selling newspaper, The Sun, forces its competitors to adopt a similar tone in an attempt to boost their own circulation figures. There may be some merit in this argument, but it is important not to overstate the claim and thereby revert back to attributing the rise of British Euroscepticism to the actions of News UK. For example, The Sun was traditionally considered to be the most important newspaper for determining the outcome of a UK general election (it took credit, for example, for the 1992 result with the headline 'It's the Sun wot won it' - although this was rather overblown). Its support for one of the major parties during an election campaign was seen as essential for any party hoping to gain office. However, during an election campaign different national newspapers have not followed the position taken by The Sun; rather they each support a political party that corresponds to their position within the UK's political space and therefore their readership. This also means that the parties they support change over time (Wring and Deacon, 2010).

The latter points to the political position of the UK national newspapers that can be situated within a two dimensional axis: they divide along the traditional left-right political spectrum, as well as a broadsheet-tabloid axis. The latter axis is particularly important given that in the UK tabloid newspapers are perceived to be more populist 
relative to the broadsheets that target the middle classes and are read by the political elite. In this respect, the political landscape of the British press is more diverse than the picture of simply being dominated by News UK suggests. In the context of the UK, what is particularly important is its domination by what Hawkins (2012) refers to as the Eurosceptic right-wing press (RWP). This includes News UK's The Sun and The Times, but also the Daily Mail, The Express and the Daily Telegraph. A more balanced opinion is given in the left-wing press (LWP) newspapers of The Guardian, The Observer and The Mirror. Reporting in the LWP challenges the Eurosceptic narrative, but despite positive coverage of the EU, a Eurosceptic discourse is also present. Furthermore, whilst pro-European voices are almost completely excluded from the RWP, space is afforded in these pro-European titles to overtly Eurosceptic voices. Thus, while the LWP offers a more balanced and less uniform account of the EU, it demonstrates the wider influence of the Eurosceptic discourse (Hawkins 2012).

While media reporting of an event or topic is hugely important, it is situated within the structural context of public opinion. Public opinion polls have demonstrated the UK’s indifference towards EU membership (up to about 60 per cent of voters have no interest in the matter, Copsey \& Haughton, 2014, p. 77). The British media therefore finds itself in an environment whereby it can either exploit that ambivalent position by taking a purely Eurosceptic tone found within the RWP, or as is done in the LWP, negotiate the tricky balancing act between supporting EU membership, but circumvent support by some critical engagement. Whether media coverage is considered as a cause of public opinion (i.e. the media leading the public) or a consequence (i.e. the public leading the media) is not important and impossible to delineate. What is important is that political actors believe that broadcast media (especially television) and newspapers determine the issue priorities of the public (Newton 2006). Walgrave and Van Aelst (2006) argue that the most important reason for political actors to adopt media issues is that media coverage is associated with public opinion. Therefore political actors consider the issue attention of the media as an indicator of the needs and wishes of the public. It is a perfectly natural reaction for politicians to take up media causes and to follow the media's prompting in some instances. Political actors are evaluated by the public based on the issues put forward by the media (Iyengar and Reeves, 1997). Not reacting to issues (widely) covered in the media might be considered as incapacity or, even worse, indifference. As a result, 
politicians tend to take up causes championed by the media, as demonstrated by David Cameron's need to 'say something about Europe'.

\section{I.I. The Triangular Relationship}

\section{DIAGRAM I TO BE INSERTED HERE}

However, while the relationship between the media and public opinion is important, it is one that both forms, and is formed by, national politics. In other words, politicians do not simply respond to cues in the media in the pluralist tradition; they are capable of shaping and determining the debate within the media, as well as influencing public opinion. Politicians use the media to gauge public reaction to their ideas and policy proposals (Davis 2007; Hefferman 2006). For example, in the build-up to an election campaign politicians will openly discuss ideas and policies in the media before formally releasing their election manifesto. The purpose here is to 'test' the public's reaction to a proposal and to ascertain the policies for which there is maximum support. Some of these policies will build on the institutional constraints of a polity, but others could represent a new way of thinking, such as that demonstrated after Margaret Thatcher's historic break with the post-war Keynesian approach to economic management.

The media/national politics/public opinion nexus provides an insight into the complex relationships between the three spheres that underpin a national political debate or policy area. We cannot assume causality in any direction, rather the purpose of research is to analyse the complex and dynamic relationship between the three spheres of the nexus, which at a particular moment in time will give rise to the contours of a political debate. Changes in one component can have important consequences for the other two: for example, the political agency demonstrated by Thatcherism to reform the British economy and to redefine the boundaries of the modern state. However, change in one component can also be more broadly limited by the other two spheres, such as Tony Blair's desire to forge a more positive relationship with the EU than the Major government through the Step Change programme (Bulmer and Burch, 2005), only to encounter resistance repeatedly from 
both the media and public opinion (Oppermann, 2008). Exogenous factors may also impact on this nexus, as was the case when The Sun began to take a noticeably more Eurosceptic line in response to Commission President Jacques Delors setting out his vision of a federal Europe (Wilkes and Wring, 1998, p. 197). Our first task is therefore to set out how the British press covers the European issue. Once this is completed, we turn to the second part of the research puzzle, which is concerned with applying this new evidence to the triangular relationship between the media, the political agenda and public opinion.

\section{Research Methodology for Analysing the EU in the British Press between the mid-1970s and the mid-2010s}

Our empirical analysis is focused solely on newspapers. The justification for this is four-fold. First of all, and most importantly, for a longitudinal analysis such as this, newspapers offer the most complete source of data for studying trends over a 40-year time period. Second, due to their in-depth and complete coverage, newspapers are more likely to be able to affect policy-makers than are other media sources (Walgrave and Van Aelst, 2006). Despite declining print circulation, the print media continue to be of enormous significance both politically and within the broader societal debates. As Wring and Deacon (2010) note, their combined readership is equal to the number of viewers of the first-ever televised debate between political leaders in a UK General Election. Their power also lies in their ability to cultivate readers over the mediumand long-term. Moreover, the Broadcasting Code requires broadcast media to report with due impartiality. These rules do not apply to print media. Third, politicians themselves, due to the more flexible and easier processing of paper material, are personally more exposed to newspapers than to television news and, hence, at least historically, have been more affected by newspapers than television (Fuchs and Pfetsch 1996). Fourth, the UK has traditionally had a much larger level of newspaper circulation than other countries (though this, of course, has undergone considerable change in recent years as print media decline). Nonetheless, according to the OECD (2010, p. 17), in the late 2000s, the UK had the third largest newspaper market in the world behind only the USA and Japan (it was also twice the size of that of Italy and three times the size of France - a considerable difference given that these two countries have comparable populations to that of the UK). 
In order to analyse the portrayal of the EU by UK newspapers three crucial methodological issues needed to be addressed: first, which newspapers to include in the analysis; second, the time period of the analysis; and third, how to categorise the reporting of the EU. These issues are addressed as follows. To gain an accurate sample of reporting from across UK newspapers we chose five national newspapers based on circulation figures provided by the Audit Bureau of Circulations and their position within the two-dimensional space mentioned above i.e. left versus right, and tabloid versus broadsheet. We therefore selected the Daily Mirror (centre-left tabloid); the Daily Mail (centre-right tabloid); the Guardian (centre-left broadsheet); the Times (centre-right broadsheet); and the Financial Times (a centre-right broadsheet commonly thought of as the most pro-EU British newspaper and which is singularly important in shaping elite perceptions - some 53\% of its UK readers are in the AB social class, and no less than $40 \%$ are London-based, Mori, 2004). We were unable to include The Sun newspaper as it does not maintain electronic records prior to 1996 . While 84 per cent of the UK population claim to have read at least one newspaper over the last 12-month period, there are some important trends to note. First, while consuming digital content of news continues to increase, 'traditional consumption (newspapers) still holds sway'. Second, younger generations are more likely to get their news from digital content, while older generations are more likely to read traditional print (YouGov 2013). Third, such a trend corresponds with support for the EU in that younger generations are more likely to hold positive views of EU membership, while older generations are more likely to hold negative views (YouGov 2015). Such trends need to be balanced against the fact that older voters have a tendency to take part in elections and referendums.

As we are interested in the changing dynamics of the EU within UK newspapers over time, our period of analysis needed to cover the UK's accession in 1973 up to the time of writing in the mid-2010s. To do this, we chose specific two-year time periods for our focus, each of which correspond to periods of increased salience of the European issue in the British press. Each one of these two-year time periods covers a Treaty negotiation or high profile event in which there was significant media coverage. Such 'focusing events' typically feature intense debates and reveal the fundamental divisions over the process of European integration, such as support for deeper 
economic and political integration or broadening the scope of integration beyond the Single Market. It also enables the analysis to pinpoint if there is a particular EU event during which Euroscepticism was able to capture the domestic debate and set the agenda thereafter.

Our analysis therefore focused on the following five time periods within the integration process: (1) 1974-75 during which the UK held a post-election referendum on membership; (2) 1985-86 during the negotiations and agreement of the Single European Act; (3) 1991-92 during negotiations on the Maastricht Treaty; (4) 2001-02 during negotiations on the Nice Treaty; and finally (5) 2012-13 around the time of David Cameron's pledge to renegotiate the UK's relationship with the EU and hold an in-or-out referendum on membership.

To identify the reporting of the EU in UK newspapers and its magnitude we constructed a coding framework. Constructing such a framework enabled the condensing of extensive qualitative data found (16,428 articles in the newspapers selected) within newspaper articles into smaller analysable units through the creation of categories and concepts derived from the data (Lockyer 2004). The framework constructed consists of three variables. The first categorises the main topic of the article, such as the Single Market, the Common Agricultural Policy, Economic and Monetary Union. To analyse the reporting of the EU we generated second (the portrayal of the EU, i.e. positive, negative, mixed, or factual) and third (magnitude, i.e. the degree of intensity with which a particular portrayal is made: high, medium or low) variables by initially analysing a cross-section of the articles. After constructing the framework it was applied to a pilot test and subsequently amended as necessary (see Gibbs, 2007, pp. 44-46). These categories are summarized in Tables I and II (available online).

Newspaper articles for each of the five different two-year time periods were manually coded in accordance with the constructed framework. Owing to the historical nature of the research, we used the electronic archive databases of the individual newspapers, such as the Financial Times Historical Archive. To ensure that all articles were retrieved in the search we used a variety of search terms used to refer to the EU during a particular time period, such as European Economic Community, EEC, 
European Communities, EC, Common Market, European Union and EU. We searched for articles in which the key search words were either in the headline/title or the first paragraph. This ensured that the search was limited to coding articles in which the EU features as the main topic. In databases where this is not possible, we searched entire articles and then manually sifted them for the criteria ourselves. The result is an extensive dataset of 16,428 entries that captures reporting of the EU in newspapers during specific high profile events since the UK membership in 1973.

Finally, to reduce the level of subjectivity in the dataset and increase the consistency of the results, both authors were initially involved in the classification of the articles. Once we had established the coding framework, two research assistants coded the majority of the articles. To ensure that they were applying the framework in an identical way, they classified one newspaper separately, compared their results, and resolved any inconsistencies. They then took the lead on specific newspapers, consulted each other on articles that were difficult to classify, and cross-checked completed datasets.

\section{Research Findings: Continuity and Change in British Press Coverage of European Issues}

Taking into account the analysis of press coverage of the European issue by British newspapers, both continuity and change are apparent across the 40-year period. To begin with points of stability in coverage, it is striking that - taken in aggregate - the total volume of stories on the EU issue did not vary hugely across the period in the five newspapers surveyed. The total number of stories published about the EU was highest around the time of the Maastricht Treaty negotiations in 1991-92, followed closely by the period of the first British referendum of 1974-75. Following these peaks, interest in the European issue seems to have waned gently, falling from around 3500 to 3750 stories annually to a trough of 2500 thousand in the mid-1980s. When it comes to the particular spin placed on a given story, 50.7 per cent of coverage was factual in nature, and 10.7 per cent neutral. Of the remaining articles 17.8 per cent were positive and 20.8 per cent were negative, although there is variation within each particular timeframe. In 1974-75 positive reporting was 22.1 per cent, while negative reporting was 16.4 per cent; 1985-86 this shifted to 17.6 and 19 per cent; while 
during 1991-92 such reporting was 18.1 per cent and 18.8 per cent. However, by 2001-02 positive reporting had fallen to 13.9 per cent and negative reporting had increased to 22.7 percent, with the figures for 2012-13 16.3 per cent and 28.4 per cent. In sum, across the five newspapers surveyed over the 40-year timeframe, 79.2 per cent of press coverage of the European issue could be described as factual, positive or neutral in nature. This is not entirely surprising given how pragmatic and cost-benefit oriented much of Britain's attitude towards the EU has been.

\section{Figure I: The reporting of the $\mathrm{EU}$ by five $\mathrm{UK}$ newspapers for selected time periods (aggregate and percentage data).}

\section{FIGURE I TO BE INSERTED HERE}

Source: Author's own data.

A number of politically important shifts can be observed between the mid-1980s and the mid-2010s once newspaper circulation is taken into account. Adjusted for the number of people who read the five newspapers in question, the outcome is rather different. We applied a weight to each of the articles based on the average daily circulation of their respective newspaper for each time period (figures obtained from the Audit Bureau of Circulations). This captures the typical exposure of each of the articles. To avoid distortions in the data between the different time periods caused by fluctuations in individual newspaper circulation, as well as an overall steady decline in print newspaper circulation, the results are captured as a percentage (figure III).

Such analysis reveals that once readership is taken into consideration, factual articles average 42.1 per cent per cent of the total over the different time periods. Negative reporting has significantly increased from 24.2 (1974-75) to 44.9 (2012-13) and this has come at the expense of positive and neutral reporting. Positive coverage has fallen from 25.2 per cent in $1974-75$ to 10.3 per cent in 2012-13. A closer analysis reveals that what took place over the period between the mid-1970s and the mid-2010s was that centre-right tabloid newspapers began to take a significantly increased interest in the dealings of the European Union, and as they did so, their coverage became steadily more negative. For 1985-86 negative reporting was 27.5 per cent, 29.7 per 
cent for 1991-92, 34.1 per cent for 2001-02, and 44.9 per cent for 2012-13. By the mid-2010s almost all coverage of the European issue in the case of the Daily Mail (85 per cent of articles) was negative. This was a remarkable shift from the position of the Daily Mail of the 1970s when 25 per cent of articles were positive (more than the negative proportion) and that of the 1980s and 1990s when less than half of total articles were negative in tone. Interestingly, on the broadsheet centre-right of the spectrum, represented by the Times and the Financial Times, no such shift took place. Total coverage of the European Union was either stable or falling over the 40-year period and such coverage as there was tended to be factual or more balanced between positive and negative.

\section{FIGURE II TO BE INSERTED HERE}

On the centre-left of the political spectrum, the picture is more complicated. The broadsheet centre-left Guardian remained solidly balanced in its reportage of the European issue between the mid-1970s and mid-2010s, with an even distribution of coverage split between positive, negative, neutral and factual. The tabloid Daily Mirror on the centre-left of the political spectrum showed an opposite trend to that of the centre-right Daily Mail. The Daily Mirror took relatively little interest in matters European throughout the mid-1970s to the mid-1990s, and when it did so, it tended to be rather negative in its outlook. About a third of articles were negative in the mid1970s and a clear majority in the mid-1980s and the mid-1990s. Yet after the 1990s, coverage of the European issue in the Daily Mirror increased three-fold by the mid2000s and then four-fold from the mid-1990s by the mid-2010s. The negative slant disappeared in favour of largely factual reporting, with, if anything, a positive stance.

Before turning to the question of what this all means, one last piece of evidence needs to be marshalled: the data that deal with the magnitude with which a particular stance towards the European issue is taken in the British press. Broadly speaking, continuity here is more important than change from the mid-1970s onwards. Here we can see that articles with a negative slant on the European issue tend to be argued in a more forthright manner when compared to those with a positive angle. Pro-European articles were in general lukewarm in comparison with the fiery vituperation levelled 
against the EU in many negative articles. A word of caution perhaps needs to be included in that newspaper coverage (indeed news in general) leans towards the gloomy (Miller and Albert, 2015). Bad news gets a greater prominence than good news and the European issue is no exception here. This finding supports that of Hawkins (2012) who argues that the negative reporting of the EU in the UK has a more damaging effect when combined with a lack of knowledge about the EU.

FIGURE III TO BE INSERTED HERE.

\section{Rethinking the Role of the Press in the Triangle of Politics, the Media and Public Opinion}

Looking across the data on newspaper coverage of the European issue, two conclusions may be drawn.

First of all, in aggregate, British newspaper reporting on the European issue has been more straightforward than is commonly supposed. Much of it is just that: reporting. It tends to be generally rather factual and whilst a bias towards negative sentiments can be found, this bias is not particularly pronounced. It could be surmised that a very significant part of the electorate, particularly those reading broadsheet articles on the EU, therefore tend to view the European issue as being largely a question of a costbenefit analysis. At the very least, this is how the European issue is covered in the newspapers they read. Second, it needs to be borne in mind that the aggregate data are only one part of the story of UK press coverage on the EU. Taking into consideration newspaper circulation, the analysis reveals a shift in UK press coverage over a fortyyear period. While factual coverage has remained relatively constant, there has been an increase in negative reporting and this has come at the expense of articles that are either positive about the EU or neutral. This shift is mainly a result of changes in the nature of reporting by centre-right tabloids. Both the aggregate data and the weighted data suggest that the structural bias within the UK media cannot be traced to a particular issue or event where things suddenly become more entrenched towards the dominance of Euroscepticism. The early 1990s are important, but the weighted reporting of articles points to Euroscepticism being dominant during the 1980s, with 27.5 per cent of coverage negative and 14.6 per cent positive. Exacerbating the 
dominance of Euroscepticism in the UK is therefore not so much one particular event, such as Maastricht, or the agency exerted by an individual, such as Murdoch, but the absence of positive coverage across the rest of the press to counter such negative articles. The absence of such a counterweight to the negative publicity of the EU therefore explains the growing support for Euroscepticism over the last thirty years. While events such as the resignation of Thatcher, Maastricht, and the influence of News UK are important, their impact is amplified owing to the structural conditions of the UK. The same is also true for EU specific factors, such as those identified by Hooghe and Marks (2009), Kriesi (2006), and Mair (2007): when they interact with the UK polity, their effects are more noticeable than other EU Member States.

What this points to is the phenomenon - for key elements of the electorate on the centre-right - of what has been termed 'issue capture’ (Copsey \& Haughton, 2014) where coverage of European Union matters is consistently and extensively cast in a negative light. Issue capture refers to the way in which a given political debate can be 'occupied' and 'dominated' by a minority group with deeply-held strong views on a given political issue. The British debate on Europe is certainly not 'owned' by a particular party or even set of parties, but the terms of the debate are determined by the vocal Eurosceptic minority in the UK. What matters is that from the point that issue capture occurs, the terms of the political debate become set by the vocal minority until such time as the issue in question can be 'recaptured' by the political mainstream. The data on the magnitude of the slant in the newspaper articles given by negative stories is grist to this mill. The diet of exclusively negative articles about the European Union, strongly expressed and argued, that is fed to some elements of the newspaper reading public on the tabloid centre-right is characteristic of the British press.

Eurobarometer polling has tracked British attitudes towards the EU over the same timeframe as our dataset (1973-2014). The conclusion that can be drawn from the polls is that the vast majority of voters do not have fixed views about the European Union, and for the most part, it is seldom an issue that is uppermost on their agenda of political priorities. The hard core of implacable Eurosceptic voters amounted to just 12 per cent of those polled over the long-term, with the equivalent figure of support for the EU ran at 25 per cent of those polled. This ambiguity towards the European 
Union that is felt by the great majority is very well reflected in the nature of the reporting in the dataset we compiled. The data for individual tabloid newspapers tell a slightly different story. In the case of the centre-left tabloid Daily Mirror, coverage of the European issue seems to have tracked the opinion of its core readership (working Labour party supporters), converting away from Euroscepticism towards Europhilia from the 1990s onwards. However, the recent decline in coverage of the EU issue in the Daily Mirror could be seen as an attempt to straddle the spilt in its readership, as some traditional working class Labour supporters have defected to UKIP (Ford and Goodwin 2014). The centre-right tabloid Daily Mail is different: although it reflected the combination of cautious support and ambivalence towards the European issue until the time of the Maastricht Treaty, following this period, even during its period of support for Tony Blair's pro-European New Labour party in the late 1990s, it did not shift its editorial stance - quite the reverse, it was during this period that it became fully Eurosceptic.

Yet what is interesting here, perhaps, is that the political debate (if not the media debate) is so influenced, or even dominated, by the noisy minority. Part of the answer to this question is to be found in the lack of passion with which the pro-European cause is made. It is the absence of this faction that gives the impression that the UK is more Eurosceptic than it truly is, and, at the same time that deprives the political debate about the EU of balance in that there are no real proponents or defenders of the EU to be found.

Within a debate that has such unusual dimensions, it should come as no surprise that there are so few politicians really willing to talk about the European Union in positive tones and, comparatively, if not in absolute numbers, so many politicians willing to talk about it a negative way. On this particular political stage, the Eurosceptic has a small but motivated and supportive audience who are likely to agree with him/her. The Europhile, on the other hand, is trying to communicate with an indifferent (albeit very large) segment of the electorate who are unlikely to be listening. Given the symbiotic relationship between politicians, the media and public opinion in the UK, it is insufficient for just one of these three elements to attempt shift; the pull of the other two will soon draw it back into a clearly delimited space. 
Thus in sketching the contours of the UK debate about the European Union, we see a political landscape that is both polarised as well as unbalanced. The polarisation is striking not because one sees an even split between Europhiles and Eurosceptics but because there are few Europhiles to match the Eurosceptics. British newspapers reflect this trend and, in our view at least, the tendency towards support for Euroscepticism in British newspapers is more a symptom of this polarisation than its cause. Ultimately, running negative articles about the EU sells newspapers. And the Eurosceptic press is not the main reason that explains why the UK's relationship with the European Union remains so difficult.

\section{Conclusions}

This article re-examined the relationship between the media, politicians and public opinion in determining British attitudes towards the European Union. It challenged two assumptions in the current literature: first, that the press is the main driver behind British Euroscepticism and that one newspaper proprietor, Rupert Murdoch, plays the lead role in setting the terms of the UK's EU debate; and second, that UK Euroscepticism crystallised during the early 1990s. We argued that the relationship between the media, national politics and public opinion is symbiotic. We therefore began our analysis of the 'European issue' in the UK from this assumption, rather than the supposition that one aspect of the relationship is the determinant of the other two. We complied an extensive dataset spanning 40 years and 16428 coded entries that provide the fullest available picture of British attitudes towards the European Union as reflected in the print media. We contextualised the evidence presented in our dataset with that on public opinion and developments in UK national politics.

The evidence put forward in this article points to a British debate about the European Union that is both unbalanced and stuck - but not for the reasons that are usually put forward. Newspapers and the voters that read them are divided between an indifferent cost-benefit motivated majority for whom the European Union is a matter of rational choice on the one hand; and, a noisy and angry minority element within society for whom almost anything to do with the European Union must be exclusively negative, on the other. In general, the British press (not only broadsheets but some tabloids as well) tends to cater for the indifferent majority rather than the noisy minority, 
although some of the right-wing press has become exclusively Eurosceptic over the last two decades. The absence of a counterweight of Europhiles that can positively argue the case for European integration has enabled 'issue capture' by a Eurosceptic minority in political debates on the EU. As a consequence, politicians have found themselves constrained by the structural dynamics of the issue: indifference to the EU is safer than being perceived as a Europhile by the electorate. Politicians that call for a more integrationist approach towards the EU are at best unrewarded by the electorate, or at worst punished.

The newspaper dataset specifically focused on high-profile EU events to see if the growth of Euroscepticism can be traced to a particular event. One important observation from our research is that the newspaper dataset and Eurobarometer data suggest that there is no 'tipping point' for the growth of Euroscepticism in the UK.

Fontana and Parsons (2015) refer to the destructive effects of the UK-EU relationship in the early 1990s, but evidence from this paper suggests otherwise. Since 1974-75 there has been a decline in positive reporting about the EU in the press and an increase in the number of articles taking a more negative position, but clearly this cannot be traced to one particular event in the UK-EU relationship. The early 1990s debate on Maastricht acted as a focusing event, in which for a period the UK-EU debate had a high political salience, but there was no significant jump in negative reporting between the early 1990s and 2001-02. The time between 2001-02 and David Cameron's announcement of a referendum on UK membership is noticeable for the increase in negative reporting, but again it would be difficult to claim that this represented a 'tipping point' in the debate.

Our findings allow for reflection on the conditions under which issue capture can occur. While a vocal minority that is able to commandeer support in the press and the political mainstream in pursuit of a particular cause may be a necessary condition for the emergence of issue capture, alone it is insufficient. More important for issue capture is the absence of effective opposition to that vocal minority. Why a Europhile opposition has not emerged in the UK is a complicated question that goes beyond the scope of this article. But it suggests a failure on the part of the political elite to address and sustain a debate surrounding the complexities of European integration 
adequately. The 2016 referendum campaign and its outcome could be seen as a symptom of this.

\section{References}

Arsenault, A. and Castells, M (2008) 'Switching Power: Rupert Murdoch and the Global Business of Media Politics: A Sociological Analysis’, International Sociology, 23 (4): 488-513.

Bulmer, S. and Burch, M (2005) 'The Europeanization of UK Government: from quiet revolution to explicit step-change?’ Public Administration 83 (4): 861-890.

Copsey, N. and Haughton, T. (2014) 'Farewell Britannia? 'Issue Capture’ and the Politics of David Cameron’s 2013 EU Referendum Pledge’, Journal of Common Market Studies Annual Review 51(1): 74-89.

Daddow, O. (2012) 'The UK Media and "Europe”: from permissive consensus to destructive dissent’. International Affairs. Vol. 88. No. 6, pp. 1219-36.

Daddow, O. (2013) 'Margaret Thatcher, Tony Blair and the Eurosceptic Tradition in Britain', The British Journal of Politics and International Relations, 15: 210-227.

Davis, A. (2007) 'Investigating Journalist Influences on Political Issue Agendas at Westminster’, Political Communication, 24: 181-199.

De Vreese, C. (2007) ‘A Spiral of Euroscepticism: The Media’s Fault?’ Acta Politica, Vol. 42, pp. 271-86.

De Vreese, C. and Kandyla, A.-A. (2009) 'News Framing and Public Support for a Common Foreign and Security Policy’. JCMS, Vol. 47, No. 3, pp. 453-81.

Duffy, B. and Rowden, L. (2004) 'You are what you read? How newspaper readership is related to views', available at: https://www.ipsosmori.com/DownloadPublication/240_sri_you_are_what_you_read_042005.pdf 
Fontana, C. and Parsons, C. (2015) ““One Woman’s Prejudice”: Did Margaret Thatcher Cause Britain’s Anti-Europeanism?’ JCMS, Vol. 53, No. 1, pp. 89-105.

Ford, R. and Goodwin, M. (2014) Revolt on the Right: Explaining Support for the Radical Right in Britain. Abingdon, Oxon: Routledge.

Forster, A. (2002) Euroscepticism in Contemporary British Politics: Opposition to Europe in the British Conservative and Labour Parties since 1945 (London: Routledge).

Fuchs, D., \& Pfetsch, B. (1996). Die beobachtung der o“ffentlichen meinung durch dasregierungssystem. In W. van den Daele \& F. Neidhart (Eds.), Kommunikation und Entscheidung. Politische funktionen o"ffentlicher meinungsbildung und diskursiver Verfahren (pp. 103-138). Berlin, Germany: WZB.

Gavin, T. (2000) 'Imagining Europe: Political Identity and British Television Coverage of the European Economy'. British Journal of Politics and International Relations, Vol. 2, No. 3, pp. 352-73.

Geddes, A. (2013) Britain and the European Union (Basingstoke: Palgrave Macmillan).

Gibbs, G. (2007) Analyzing Qualitative Data. London: Sage.

Glencross. A. (2015) 'Why a British Referendum Will Not Solve the Europe Question’. International Affairs, Vol. 91, pp. 303-17.

Hawkins, B. (2012) 'Nation, Separation and Threat: An Analysis of British Media Discourses on the European Union Treaty Reform Process', Journal of Common Market Studies, 50 (4): 561-577. 
Hooghe, L. and Marks, G. (2009) 'A Postfunctionalist Theory of European Integration: From Permissive Consensus to Constraining Dissensus’. British Journal of Political Science, Vol. 39, Issue 1, pp. 1-23.

Hefferman, R. (2006) 'The Prime Minister and the News Media: Political Communication as a Leadership Resource’, 59 (4): 582-598.

Iyengar, S. and Reeves, R. (1997) Do the Media Govern? Politicians, voters and reporters in America. Thousand Oaks, CA: Sage.

Kriesi, H. et al. (2006) 'Globalisation and the Transformation of the National Political Space: Six European Countries Compared'. European Journal of Political Research, Vol. 45, pp. 921-56.

Lockyer, S. (2004) 'Coding Qualitative Data’, in M.S. Lewis-Beck, A. Bryman and T. Futing Liao (eds) The Sage Encyclopedia of Social Science Research Methods (pp. 137-38). California: Sage.

Mair, P. (2005) 'Popular Democracy and the European Union Polity’. European Governance Papers C-05-30.

Mair, P. (2007) ‘Political Opposition and the European Union’. Government and Opposition, Vol. 42, No. 1, pp. 1-17.

Mair, P. and Smith, G. (1989) Understanding Party System Change (London: Frank Cass).

Miller, R.A. and Albert, K. (2015) 'If it Leads, It Bleeds (and If It Bleeds, It Leads): Media Coverage and Fatalities in Militarised Interstate Disputes', Political Communication, Vol. 32, No. 1, pp. 61-82.

Newton, K. (2006) 'May the Weak Force Be with You: The Power of the Mass Media in Modern Politics, 45 (2): 209-234. 
OECD (2010) 'Working Party on the Information Economy: The Evolution of News and the Internet' available at: http://www.oecd.org/sti/ieconomy/45559596.pdf (accessed 25/06/2015).

Oppermann, K. (2008) 'The Blair Government and Europe: the Policy of Containing the Salience of European Integration’ British Politics, 3(2): 156-182.

Prosser, C. (2016) 'Calling European Union Treaty Referendums: Electoral and Institutional Politics’. Political Studies, Vol. 64, No. 1, pp. 182-99.

Schmidt, V. (2003) 'European Integration as Regional Variant of Globalisation: the challenges to national democracy’. In Katenhusen, I. and Lamping, W. (eds), Demokratien in Europa (VS Verlag für Sozialwissenschaften).

Vliegenthardt, R. et al. (2008) 'News Coverage and Support for European Integration, 1990-2006'. International Journal of Public Opinion Research, Vol. 20, No. 4, pp. 415-39.

Walgrave, S. and Van Aelst, P. (2006) ‘ The Contingency of Mass Media’s Poltical Agenda Setting Power: Toward a Preliminary Theory', Journal of Communication, 56: 88-109.

Wilkes, G. and Wring, D. (1998) 'The British Press and European Integration: 194896'. In Baker, D. and Seawright. D. Britain For and Against Europe (Oxford: OUP).

Wring, D. and Deacon, D. (2010) 'Patterns of Press Partisanship in the 2010 General Election’, British Politics, Vol. 5, pp. 436-54.

YouGov (2015) Analysis: EU Referendum: the state of public opinion. Available at: https://yougov.co.uk/news/2015/09/22/eu-referendum-state-public-opinion/ - accessed 19/05/2016. 
YouGov (2013) Britain’s Changing Media Habits. Available at:

http://cdn.yougov.com/cumulus uploads/document/jrlh273vq2/YG-G-Changing-

Media-Summit-Report-PARTI.pdf - accessed 19/05/2016.

Young (1999) This Blessed Plot: Britain and the Europe from Churchill to Blair (London: Papermac). 
Diagram I:

\section{National \\ Politics}

\section{Media}

\section{Public \\ Opinion}

Figure I: The reporting of the EU by five UK newspapers for selected time periods (aggregate and percentage data).

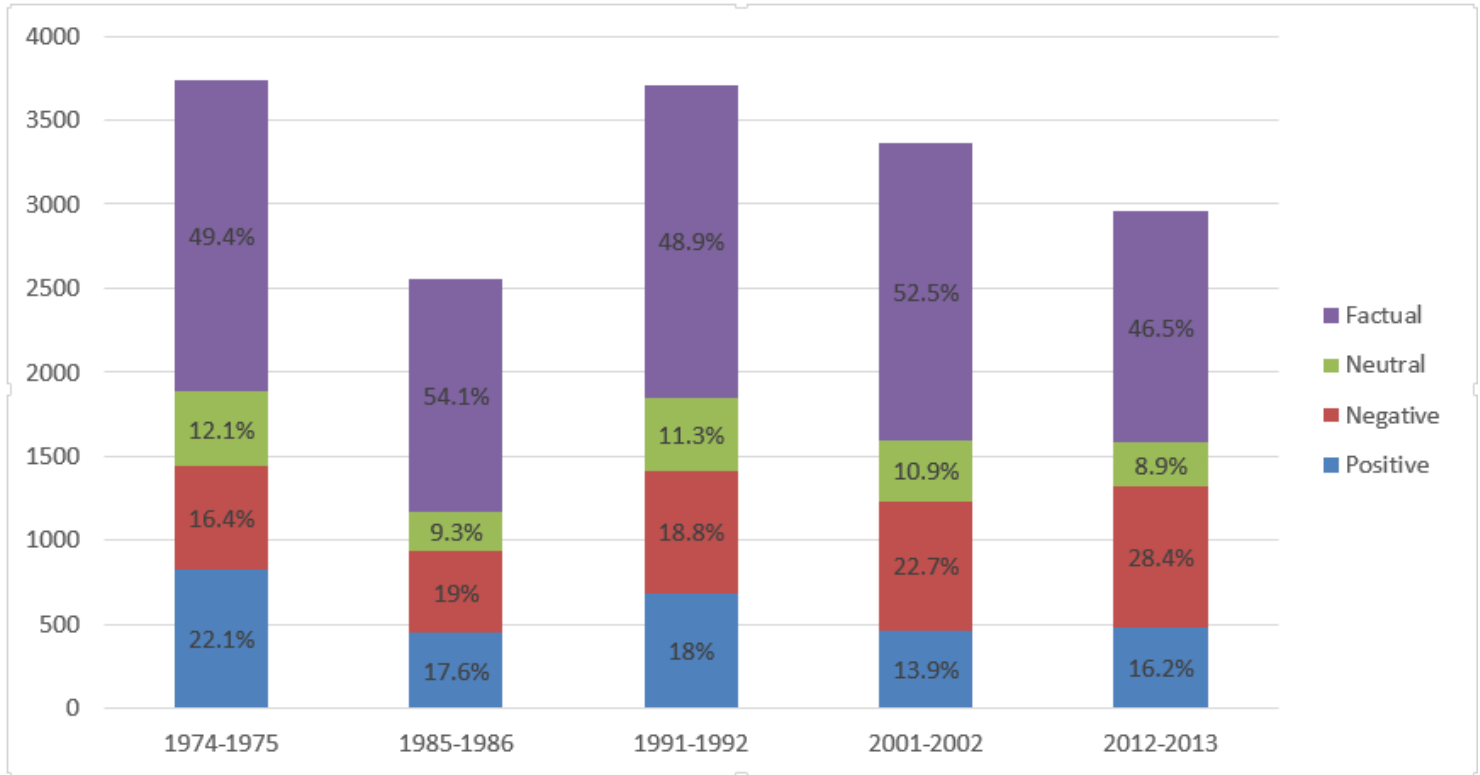


Figure II: The reporting of the EU by five UK newspapers for selected time periods adjusted for by average daily circulation

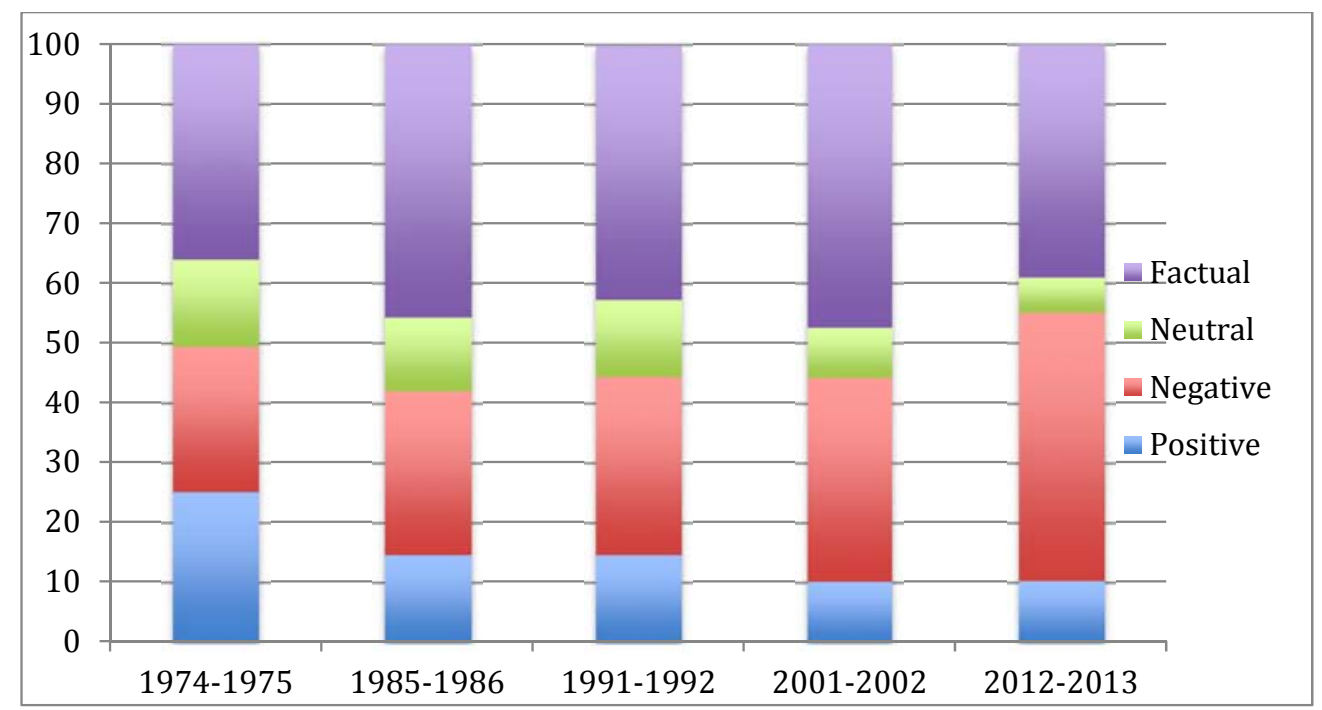

Figure III: The magnitude of both positive and negative reporting in UK newspapers for selected time periods (as a percentage)

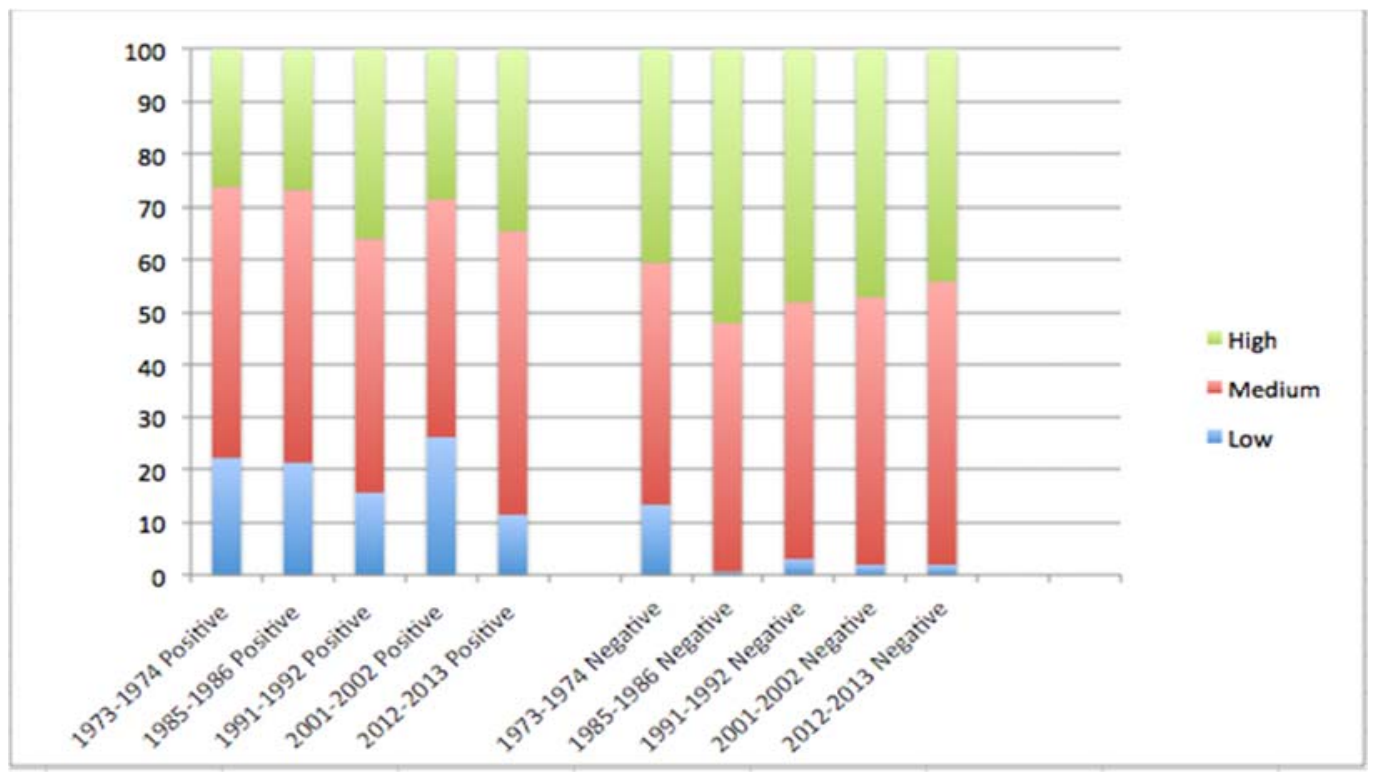


Table I: Coding Framework for Portrayal of the EU in Newspaper Articles

\begin{tabular}{|l|l|}
\hline Coding & Descriptor \\
\hline Positive & $\begin{array}{l}\text { Supportive of current developments within the process of European integration and the } \\
\text { UK being a member. It is a good thing that the UK is in the EU or the EU brings benefits } \\
\text { to the UK or other countries or the Continent or certain groups of individuals. Such } \\
\text { positive expressions are to be also found within the opinion of the journalist, or in the } \\
\text { quotes given by individuals used within the article, or the factual evidence. }\end{array}$ \\
\hline Negative & $\begin{array}{l}\text { Expresses concern and/or dissatisfaction with current developments in the EU and/or the } \\
\text { UK's position as a member state. The EU or the UK's Membership of the EU creates } \\
\text { problems for the UK, other Member States or the Continent. The impact of the EU is } \\
\text { negative. Such negative expressions are to be also found within the opinion of the } \\
\text { journalist, or in the quotes given by individuals used within the article. }\end{array}$ \\
\hline Mixed & $\begin{array}{l}\text { Expresses both satisfaction and dissatisfaction with either the process of European } \\
\text { integration and/or the UK's position as a member or for certain groups of individuals. }\end{array}$ \\
\hline Factual & $\begin{array}{l}\text { Article is factual and presents events in a fair and unbiased way allowing the reader to } \\
\text { gain information on the EU, and the UK's relationship with the EU, without it being } \\
\text { tainted by the opinions of the newspaper. }\end{array}$ \\
\hline
\end{tabular}

Table II: Coding Framework for the Magnitude of Positive or Negative Portrayal of the EU in Newspaper Articles

\begin{tabular}{|c|c|}
\hline Magnitude & Definition \\
\hline \multicolumn{2}{|l|}{ Positive } \\
\hline High & $\begin{array}{l}\text { The process of European integration should go further/deeper. Membership of the } \\
\text { EU is a good thing. }\end{array}$ \\
\hline Medium & $\begin{array}{l}\text { Overall the process of European integration is positive, but there is no call for the } \\
\text { process to go further. }\end{array}$ \\
\hline Low & Overall the process of European integration is positive, but it can be improved. \\
\hline \multicolumn{2}{|l|}{ Negative } \\
\hline High & The UK should leave the EU. \\
\hline Medium & In part, the EU creates problems or is responsible for problems in the UK. \\
\hline Low & The direction of integration is broadly negative and should be reformed. \\
\hline
\end{tabular}

